Correspondence

Jung-Hoon Yoon

jhyoon@kribb.re.kr

\section{Erythrobacter aquimaris sp. nov., isolated from sea water of a tidal flat of the Yellow Sea in Korea}

\author{
Jung-Hoon Yoon, ${ }^{1}$ Kook Hee Kang, ${ }^{2}$ Tae-Kwang Oh ${ }^{1}$ and Yong-Ha Park ${ }^{1}$ \\ ${ }^{1}$ Korea Research Institute of Bioscience and Biotechnology (KRIBB), PO Box 115, Yusong, \\ Taejon, Korea \\ ${ }^{2}$ Department of Food and Life Science, Sungkyunkwan University, Chunchun-dong 300, \\ Jangan-gu, Suwon, Korea
}

\begin{abstract}
Three Gram-negative, non-motile, non-spore-forming, slightly halophilic rods (strains SW-110 ${ }^{\top}, \mathrm{SW}-116$ and SW-140) were isolated from sea water of a tidal flat of the Yellow Sea in Korea and subjected to a polyphasic taxonomic study. The three isolates did not produce bacteriochlorophyll $a$ and were characterized chemotaxonomically by having ubiquinone- 10 as the predominant respiratory lipoquinone and $\mathrm{C}_{18: 1} \omega 7 c$ and $\mathrm{C}_{17: 1} \omega 6 c$ as the major fatty acids. The DNA G + C content of the three isolates was between $62 \cdot 2$ and $62.9 \mathrm{~mol} \%$. Strains $\mathrm{SW}-110^{\top}$, SW-116 and SW-140 showed no difference in their 16S rRNA gene sequences, and their mean level of DNA-DNA relatedness was $94.8 \%$. Phylogenetic analyses based on 16S rRNA gene sequences showed that the three strains form a distinct phylogenetic lineage within the cluster comprising Erythrobacter species. Similarities between the 16S rRNA gene sequences of strains SW-110 ${ }^{\top}, \mathrm{SW}-116$ and SW-140 and the type strains of Erythrobacter species ranged from 98.4\% (with Erythrobacter longus) to $97 \cdot 7 \%$ (with Erythrobacter flavus). Levels of DNA-DNA relatedness between strains $\mathrm{SW}-110^{\top}, \mathrm{SW}-116$ and $\mathrm{SW}-140$ and the type strains of all recognized Erythrobacter species were in the range $5 \cdot 3-12 \cdot 7 \%$. On the basis of polyphasic taxonomic data, strains SW-110 ${ }^{\top}, \mathrm{SW}-116$ and $\mathrm{SW}-140$ were classified as a novel Erythrobacter species, for which the name Erythrobacter aquimaris sp. nov. is proposed. The type strain is SW $-110^{\top}\left(=\right.$ KCCM $41818^{\top}=$ JCM $\left.12189^{\top}\right)$.
\end{abstract}

The genus Erythrobacter was proposed by Shiba \& Simidu (1982) with a single species, Erythrobacter longus. Phylogenetically, the genus Erythrobacter belongs to the $\alpha$-subclass of the Proteobacteria (Anzai et al., 2000). The first two Erythrobacter species recognized, E. longus and Erythrobacter litoralis (Yurkov et al., 1994), were red or orange in colour and contained bacteriochlorophyll (BChl) $a$ and carotenoids (Shiba \& Simidu, 1982; Yurkov et al., 1994). Recently, two yellow-pigmented Erythrobacter species, lacking BChl $a$, have been described, Erythrobacter citreus and Erythrobacter flavus (Denner et al., 2002; Yoon et al., 2003). We report here on the detailed taxonomic characterization of three slightly halophilic, orange-pigmented, Erythrobacter-like bacterial strains, SW-110 ${ }^{\mathrm{T}}$, SW-116 and SW-140, which were isolated from sea water of a tidal flat of the Yellow Sea in Korea.

Strains SW-110 ${ }^{\mathrm{T}}$, SW-116 and SW-140 were isolated using the dilution plating technique on marine agar 2216 (MA;

\footnotetext{
Abbreviations: BChl, bacteriochlorophyll; FAME, fatty acid methyl ester. The GenBank/EMBL/DDBJ accession numbers for the 16S rRNA gene sequences of strains SW-110 ${ }^{\top}, \mathrm{SW}-116$ and $\mathrm{SW}-140$ are AY461441, AY461442 and AY461443, respectively.
}

Difco). E. longus DSM 6997 ${ }^{\mathrm{T}}$, E. litoralis DSM $8509^{\mathrm{T}}$ and E. citreus DSM $14432^{\mathrm{T}}$ were obtained from the DSMZ. E. flavus KCCM $41642^{\mathrm{T}}$ was obtained from the study of Yoon et al. (2003). Cell biomass of strains SW-110 ${ }^{\mathrm{T}}$, SW-116 and SW-140 for respiratory lipoquinone analysis and for DNA extraction was obtained from cultures in marine broth 2216 (MB; Difco) at $30^{\circ} \mathrm{C}$. For fatty acid methyl ester (FAME) analysis, cell mass of strains SW $-110^{\mathrm{T}}$, SW-116 and SW-140 was obtained from agar plates after cultivation for 5 days at $30{ }^{\circ} \mathrm{C}$ on MA. Cell morphology was examined by light microscopy (Nikon E600) and transmission electron microscopy (TEM). Presence or absence of flagella was examined using TEM with cells from exponentially growing cultures. The cells were negatively stained with $1 \%(\mathrm{w} / \mathrm{v})$ phosphotungstic acid and the grids were examined after air drying with a Philips CM-20 transmission electron microscope. Growth under anaerobic conditions was determined after incubation in a Forma anaerobic chamber with MA that had been prepared anaerobically using nitrogen. Growth in the absence of $\mathrm{NaCl}$ was investigated in trypticase soy broth (Difco) without $\mathrm{NaCl}$. Growth at various $\mathrm{NaCl}$ concentrations was investigated in $\mathrm{MB}$. Growth at $4-45^{\circ} \mathrm{C}$ was measured on MA. Catalase and oxidase activities and hydrolysis of casein, starch and Tweens 20, 40, 60 and 80 
were determined as described by Cowan \& Steel (1965). Hydrolysis of hypoxanthine, tyrosine and xanthine was tested on MA with substrate concentrations as described by Cowan \& Steel (1965). Hydrolysis of aesculin, gelatin and urea and nitrate reduction were studied as described by Lanyi (1987) with a modification that artificial sea water was used for preparation of media. The artificial sea water contained (per litre of distilled water) $23.6 \mathrm{~g} \mathrm{NaCl}, 0.64 \mathrm{~g}$ $\mathrm{KCl}, 4.53 \mathrm{~g} \mathrm{MgCl}_{2} .6 \mathrm{H}_{2} \mathrm{O}$, 5.94 g $\mathrm{MgSO}_{4} .7 \mathrm{H}_{2} \mathrm{O}$ and $1.3 \mathrm{~g}$ $\mathrm{CaCl}_{2} \cdot 2 \mathrm{H}_{2} \mathrm{O}$ (Levring, 1946). $\mathrm{H}_{2} \mathrm{~S}$ production was tested as described by Bruns et al. (2001). For in vivo pigmentabsorption spectrum analysis, three strains were cultivated aerobically in the dark at $30^{\circ} \mathrm{C}$ in $\mathrm{MB}$, PYGV medium (Fuerst et al., 1993; DSMZ medium no. 621) and Erythromicrobium/Roseococcus medium (Yurkov et al., 1994; DSMZ medium no. 767). E. longus DSM $6997^{\mathrm{T}}$ and E. litoralis DSM $8509^{\mathrm{T}}$ were used as positive controls for spectrum analysis. Cultures were washed twice by centrifugation using a MOPS buffer (MOPS/NaOH, 0.01 M; KCl, $0 \cdot 1 \mathrm{M} ; \mathrm{MgCl}_{2}$, $0.001 \mathrm{M} ; \mathrm{pH} 7.5)$ and disrupted by sonication with a Branson Sonifier 450. After removal of cell debris, the absorption spectrum of the supernatant was examined on a Beckman Coulter DU800 spectrophotometer. Susceptibility to antibiotics was detected on MA plates by using antibiotic discs (Advantec) (concentrations are given in Table 1). Acid production from carbohydrates was determined as described by Leifson (1963). Utilization of various substrates for growth was determined as described by Yurkov et al. (1994).

Respiratory lipoquinones were analysed as described by Komagata \& Suzuki (1987) using reversed-phase HPLC. For quantitative analysis of cellular fatty acid composition, a loop of cell mass was harvested and FAMEs were extracted and prepared according to the standard protocol of the MIDI/Hewlett Packard Microbial Identification System (Sasser, 1990). Chromosomal DNA was isolated and purified according to the method described by Yoon et al. (1996), with the exception that ribonuclease $\mathrm{T} 1$ was used together with ribonuclease A. The DNA G $+\mathrm{C}$ content was determined by the method of Tamaoka \& Komagata (1984). DNA was hydrolysed and the resultant nucleotides were analysed by reversed-phase HPLC. 16S rRNA genes were amplified by PCR using two universal primers as described by Yoon et al. (1998). Sequencing of the amplified 16S rRNA gene was performed as described by Yoon et al. (2003). Alignment of sequences was carried out with CLUSTAL W software (Thompson et al., 1994). Gaps at the

Table 1. Differential phenotypic characteristics of Erythrobacter aquimaris sp. nov., E. longus, E. litoralis, E. citreus and E. flavus

Species: 1, E. aquimaris sp. nov.; 2, E. longus (data from Shiba \& Simidu, 1982; Yurkov et al., 1994); 3, E. litoralis (Shiba \& Simidu, 1982; Yurkov et al., 1994); 4, E. citreus (Denner et al., 2002; Vybiral et al., 1999); 5, E. flavus (Yoon et al., 2003). +, Positive; -, negative; W+, weakly positive; ND, not determined; V, variable. Data in parentheses are for the type strain. All species are rod-shaped and positive for catalase and oxidase, susceptibility to chloramphenicol (100 $\mu \mathrm{g}$ per disc; $30 \mu \mathrm{g}$ per disc for E. citreus) and utilization of acetate. All species are Gram-negative, non-sporulating and resistant to $100 \mathrm{U}$ polymyxin B per disc (300 U per disc for E. citreus).

\begin{tabular}{|c|c|c|c|c|c|}
\hline Characteristic & 1 & 2 & 3 & 4 & 5 \\
\hline Colour of colonies & Orange & Orange & Red or orange & Yellow & Yellow \\
\hline Motility & - & + & + & - & + \\
\hline Presence of BChl $a$ & - & + & + & - & - \\
\hline Nitrate reduction & - & $\mathrm{v}(+)$ & - & + & - \\
\hline \multicolumn{6}{|l|}{ Hydrolysis of: } \\
\hline Gelatin & - & + & - & $\mathrm{ND}$ & - \\
\hline Starch & $\mathrm{V}(+)$ & - & - & $(-)$ & + \\
\hline \multicolumn{6}{|l|}{ Utilization of: } \\
\hline Glucose & + & + & + & $\mathrm{V}(\mathrm{W}+)$ & - \\
\hline Fructose & - & ND & + & $(-)$ & - \\
\hline Citrate & - & - & - & $\mathrm{V}(\mathrm{W}+)$ & - \\
\hline Pyruvate & + & + & + & - & + \\
\hline Glutamate & - & + & + & ND & - \\
\hline Succinate & + & - & + & ND & - \\
\hline Lactate & - & - & + & - & $\mathrm{V}$ \\
\hline Malate & + & - & - & - & - \\
\hline \multicolumn{6}{|l|}{ Susceptibility to: } \\
\hline Penicillin (20 U; $10 \mathrm{U}$ for E. citreus) & - & - & - & $\mathrm{V}$ & - \\
\hline Streptomycin $(50 \mu \mathrm{g} ; 10 \mu \mathrm{g}$ for E. citreus) & - & - & - & $\mathrm{V}$ & - \\
\hline Optimum growth temperature $\left({ }^{\circ} \mathrm{C}\right)$ & $30-37$ & $25-30$ & $25-30$ & ND & $30-37$ \\
\hline DNA G $+\mathrm{C}$ content $(\mathrm{mol} \%)$ & $62 \cdot 2-62 \cdot 9$ & $60-64(60 \cdot 7)$ & 67 & $62 \cdot 0-62 \cdot 4$ & $64 \cdot 0-64 \cdot 1$ \\
\hline
\end{tabular}


$5^{\prime}$ and $3^{\prime}$ ends of the alignment were omitted from further analysis. Phylogenetic trees were inferred by using three tree-making algorithms; the neighbour-joining (Saitou \& Nei, 1987), maximum-likelihood (Felsenstein, 1981) and maximum-parsimony (Kluge \& Farris, 1969) methods were performed using the PHYLIP package (Felsenstein, 1993). Evolutionary distance matrices for the neighbour-joining method were calculated with the algorithm of Jukes \& Cantor (1969) with the DNADIST program. Stability of relationships was assessed by a bootstrap analysis based on 1000 resamplings of the neighbour-joining dataset using the programs SEQBOOT, DNADIST, NEIGHBOR and CONSENSE of the PHYLIP package. DNA-DNA hybridization was performed fluorometrically by the method of Ezaki et al. (1989) using photobiotin-labelled DNA probes and microdilution wells. Hybridization was performed using five replications for each sample. The highest and lowest values obtained in each sample were excluded, and the remaining three values were used to calculate relatedness values. The DNA relatedness values quoted are the mean of the three values.

Strains SW-110 ${ }^{\mathrm{T}}$, SW-116 and SW-140 were similar in most phenotypic characteristics. After 5 days of cultivation at $30{ }^{\circ} \mathrm{C}$ on MA, cells were rods, approximately $0.6-0.9 \mu \mathrm{m}$ wide by $2 \cdot 0-4 \cdot 0 \mu \mathrm{m}$ long. No flagella were located by TEM. Colonies were $1 \cdot 0-2 \cdot 0 \mathrm{~mm}$ in diameter, smooth, glistening, circular, convex and orange-pigmented after 5 days of incubation at $30^{\circ} \mathrm{C}$ on MA. Strain SW- $-110^{\mathrm{T}}$ was slightly darker pigmented than strains SW-116 and SW-140. The strains grew optimally at $30-37^{\circ} \mathrm{C}$; growth was observed at 10 but not at $4{ }^{\circ} \mathrm{C}$. The maximum growth temperature of strains SW $-110^{\mathrm{T}}$ and $\mathrm{SW}-116$ was $40^{\circ} \mathrm{C}$, and that of strain SW- 140 was $41^{\circ} \mathrm{C}$. Optimal $\mathrm{pH}$ for growth was between 6.5 and $7 \cdot 5$; no growth was observed at $\mathrm{pH} 5 \cdot 0$. All strains were slightly halophilic; optimal growth occurred at $2-3 \%$ $(\mathrm{w} / \mathrm{v}) \mathrm{NaCl}$, and there was no growth in the absence of $\mathrm{NaCl}$. Strains SW $-110^{\mathrm{T}}$ and SW-116 did not tolerate $>10 \%$ $(\mathrm{w} / \mathrm{v}) \mathrm{NaCl}$, and strain SW-140 did not tolerate $>9 \%(\mathrm{w} / \mathrm{v})$ $\mathrm{NaCl}$. The strains did not grow on MA under anaerobic conditions. Starch was hydrolysed by strains $\mathrm{SW}-110^{\mathrm{T}}$ and SW-140, but not by strain SW-116. The sonicated cell extracts of strains SW-110 ${ }^{\mathrm{T}}$, SW-116 and SW-140 did not display absorption maxima characteristic for BChl $a$ in three different media. Other physiological and biochemical characteristics are shown in Table 1 or are given in the species description below. Phenotypic characteristics that differentiate strains $\mathrm{SW}-110^{\mathrm{T}}$, SW-116 and SW-140 from Erythrobacter species are summarized in Table 1.

Strains SW- $110^{\mathrm{T}}$, SW-116 and SW-140 had ubiquinone with ten isoprene units (Q-10) as the predominant respiratory lipoquinone at a peak ratio of approximately $90-93 \%$. The fatty acid profiles of the orange-pigmented isolates were characterized by a common core of unsaturated fatty acids $\mathrm{C}_{18: 1} \omega 7 c$ and $\mathrm{C}_{17: 1} \omega 6 c$ and straight-chain fatty acid $\mathrm{C}_{16: 0}$ in varying amounts; hydroxy fatty acids were also present. The general fatty acid profile was similar between the isolates and Erythrobacter species. However, strains SW-110 ${ }^{\mathrm{T}}$,
SW-116 and SW-140 differed from Erythrobacter species in the total number of fatty acids and relative abundance of shared components (Table 2). The DNA G $+\mathrm{C}$ contents of strains SW-110 ${ }^{\mathrm{T}}$, SW-116 and SW-140 were $62 \cdot 2,62 \cdot 9$ and $62 \cdot 7 \mathrm{~mol} \%$, respectively.

The 16S rRNA gene sequences of the three strains determined in this study each comprised $1444 \mathrm{nt}$, representing approximately $96 \%$ of the Escherichia coli $16 \mathrm{~S}$ rRNA gene sequence. Strains $\mathrm{SW}-110^{\mathrm{T}}$, SW-116 and SW-140 showed no difference in their 16S rRNA gene sequences. Comparative $16 \mathrm{~S}$ rRNA gene sequence analyses showed that the three strains are phylogenetically closely related to Erythrobacter species of the Sphingomonadaceae. Similarities between the $16 \mathrm{~S}$ rRNA gene sequences of strains SW-110 ${ }^{\mathrm{T}}$, SW-116 and SW-140 with Erythrobacter species ranged from 98.4\% (with E. longus) to $97 \cdot 7 \%$ (with E. flavus). Fig. 1 shows a

Table 2. Percentage cellular fatty acid composition of strains $\mathrm{SW}-110^{\top}, \mathrm{SW}-116$ and $\mathrm{SW}-140$ (E. aquimaris sp. nov.) and type strains of Erythrobacter species

Strains: 1, E. aquimaris $\mathrm{SW}-110^{\mathrm{T}} ; 2$, E. aquimaris SW-116; 3, E. aquimaris SW-140; 4, E. longus DSM $6997^{\mathrm{T}}$ (data from Yoon et al., 2003); 5, E. litoralis DSM $8509^{\mathrm{T}}$ (Yoon et al., 2003); 6, E. flavus KCCM $41642^{\mathrm{T}}$ (Yoon et al., 2003); 7, E. citreus RE35F $/ 1^{\mathrm{T}}$ (Denner et al., 2002). - , Not detected. Fatty acids representing less than $0.5 \%$ in all strains were omitted.

\begin{tabular}{|c|c|c|c|c|c|c|c|}
\hline Fatty acid & 1 & 2 & 3 & 4 & 5 & 6 & 7 \\
\hline \multicolumn{8}{|l|}{ Straight-chain: } \\
\hline $\mathrm{C}_{15: 0}$ & $2 \cdot 7$ & $1 \cdot 6$ & $2 \cdot 4$ & $2 \cdot 8$ & $0 \cdot 5$ & $3 \cdot 0$ & $0 \cdot 3$ \\
\hline $\mathrm{C}_{16: 0}$ & $10 \cdot 3$ & $5 \cdot 5$ & $7 \cdot 5$ & $11 \cdot 4$ & $2 \cdot 7$ & $6 \cdot 4$ & $8 \cdot 2$ \\
\hline$C_{17: 0}$ & $3 \cdot 2$ & $1 \cdot 2$ & $1 \cdot 4$ & $10 \cdot 1$ & - & $7 \cdot 3$ & - \\
\hline $\mathrm{C}_{18: 0}$ & $0 \cdot 4$ & - & - & $1 \cdot 0$ & - & $0 \cdot 5$ & - \\
\hline \multicolumn{8}{|l|}{ Branched: } \\
\hline Anteiso- $\mathrm{C}_{15: 0}$ & - & - & - & - & - & - & $0 \cdot 6$ \\
\hline Anteiso- $\mathrm{C}_{16: 0}$ & - & - & - & - & - & - & $0 \cdot 7$ \\
\hline Anteiso- $\mathrm{C}_{17: 0}$ & - & - & - & - & - & - & $1 \cdot 2$ \\
\hline \multicolumn{8}{|l|}{ Unsaturated: } \\
\hline $\mathrm{C}_{16: 1} \omega 5 c$ & $1 \cdot 3$ & $1 \cdot 1$ & $1 \cdot 4$ & - & $0 \cdot 7$ & - & $3 \cdot 6$ \\
\hline $\mathrm{C}_{17: 1} \omega 6 c$ & $27 \cdot 6$ & $25 \cdot 0$ & $23 \cdot 6$ & $3 \cdot 9$ & $28 \cdot 5$ & $6 \cdot 2$ & $5 \cdot 6$ \\
\hline $\mathrm{C}_{17: 1} \omega 8 c$ & $2 \cdot 5$ & $4 \cdot 5$ & $2 \cdot 3$ & $4 \cdot 8$ & $4 \cdot 3$ & $8 \cdot 1$ & $0 \cdot 7$ \\
\hline $\mathrm{C}_{18: 1} \omega 5 c$ & $1 \cdot 5$ & $1 \cdot 3$ & $1 \cdot 3$ & - & $2 \cdot 2$ & - & $4 \cdot 2$ \\
\hline $\mathrm{C}_{18: 1} \omega 7 \mathrm{c}$ & $26 \cdot 8$ & $32 \cdot 0$ & $30 \cdot 7$ & $50 \cdot 9$ & $46 \cdot 9$ & $46 \cdot 2$ & $49 \cdot 3$ \\
\hline 11-Methyl- $\mathrm{C}_{18: 1} \omega 7 c$ & $4 \cdot 4$ & $8 \cdot 3$ & $6 \cdot 6$ & - & $3 \cdot 7$ & $5 \cdot 5$ & $4 \cdot 4$ \\
\hline \multicolumn{8}{|l|}{ Hydroxy: } \\
\hline $\mathrm{C}_{14: 0} 2-\mathrm{OH}$ & $3 \cdot 9$ & $5 \cdot 2$ & $6 \cdot 3$ & $5 \cdot 0$ & $2 \cdot 9$ & $0 \cdot 9$ & $0 \cdot 9$ \\
\hline $\mathrm{C}_{15: 0} 2-\mathrm{OH}$ & $7 \cdot 4$ & $6 \cdot 7$ & $6 \cdot 8$ & $8 \cdot 6$ & $2 \cdot 6$ & $9 \cdot 5$ & - \\
\hline $\mathrm{C}_{16: 0} 2-\mathrm{OH}$ & $2 \cdot 2$ & $2 \cdot 0$ & $1 \cdot 9$ & $1 \cdot 5$ & $1 \cdot 5$ & $1 \cdot 4$ & - \\
\hline $\mathrm{C}_{18: 1} 2-\mathrm{OH}$ & $0 \cdot 5$ & $0 \cdot 9$ & $0 \cdot 6$ & - & - & $0 \cdot 3$ & $2 \cdot 0$ \\
\hline Iso- $\mathrm{C}_{16: 0} 3-\mathrm{OH}$ & - & - & - & - & $1 \cdot 1$ & - & $1 \cdot 0$ \\
\hline Summed feature $3^{*}$ & $4 \cdot 6$ & $4 \cdot 8$ & $6 \cdot 0$ & - & $2 \cdot 3$ & $4 \cdot 6$ & $14 \cdot 9$ \\
\hline
\end{tabular}

${ }^{*}$ Summed features represent groups of two or three fatty acids that could not be separated by GLC with the MIDI system. Summed feature 3 contained iso- $\mathrm{C}_{15: 0} 2-\mathrm{OH}$ and/or $\mathrm{C}_{16: 1} \omega 7 c$. 


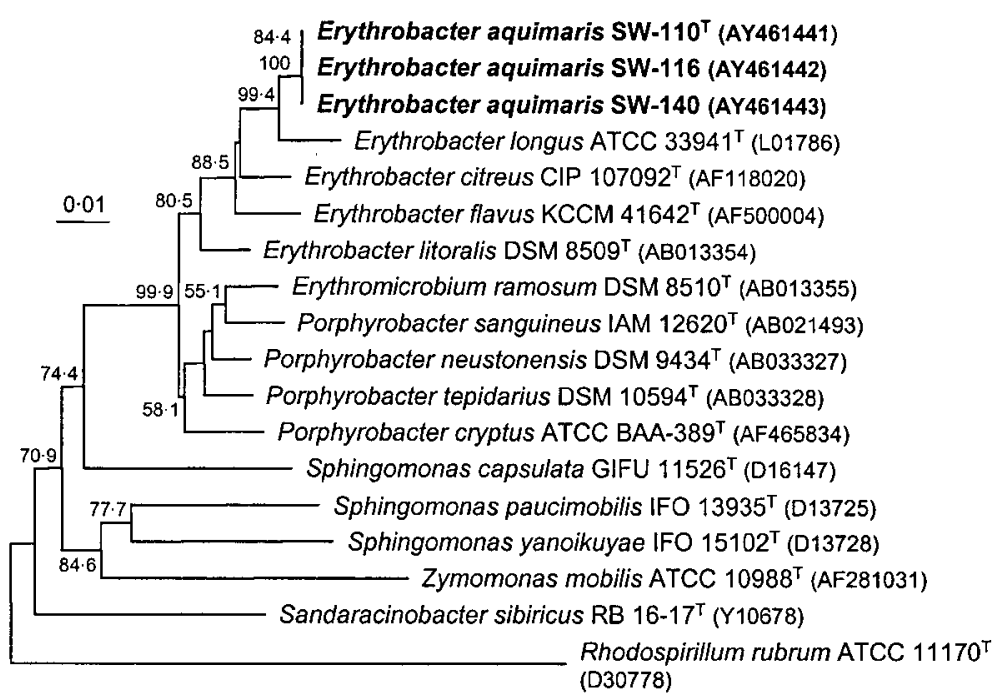

Fig. 1. Neighbour-joining tree based on 16S rRNA gene sequence data showing the phylogenetic position of strains $\mathrm{SW}-110^{\top}$, SW-116 and SW-140 within the Sphingomonadaceae. Bootstrap values (1000 replications) are shown as percentages at each node only if they are $50 \%$ or greater. Bar, 0.01 substitutions per nucleotide position. Rhodospirillum rubrum ATCC $11170^{\top}$ was used as the outgroup. dendrogram of estimated phylogenetic relationships, inferred from comparisons of 16S rRNA gene sequences between the three isolates and all recognized Erythrobacter species and with some other species of the $\alpha$-Proteobacteria. A 16S rRNA gene sequence similarity of $>97 \%$ clearly indicates that the three strains are closely related phylogenetically to Erythrobacter species but does not allow us to evaluate confidently whether the three isolates should be considered to represent a separate species. Sequence similarities to all other species of the Sphingomonadaceae included in the phylogenetic analysis were lower than $96.6 \%$ (Fig. 1). Levels of DNA-DNA relatedness observed between strains SW- $110^{\mathrm{T}}$, SW-116 and SW-140 were 88.5$102 \cdot 1 \%$, suggesting that the strains belong to the same species (Wayne et al., 1987). Levels of DNA-DNA relatedness to reference type strains of recognized Erythrobacter species were between $5 \cdot 3$ and $12 \cdot 7 \%$. This genomic evidence demonstrates that the three strains represent a separate species within the genus Erythrobacter (Wayne et al., 1987).

$16 \mathrm{~S}$ rRNA gene sequence comparison showed that strains SW-110 ${ }^{\mathrm{T}}$, SW-116 and SW-140 exhibited the closest phylogenetic affinities to Erythrobacter species (Fig. 1). The relationship between the cluster comprising the three strains and Erythrobacter species and the cluster comprising the genera Porphyrobacter and Erythromicrobium was supported by a high bootstrap resampling value of $99 \cdot 9 \%$ (Fig. 1). The results obtained in the morphological and chemotaxonomic analyses are consistent with the result of the monothetic classification by $16 \mathrm{~S}$ rRNA gene sequence analysis, although clear chemotaxonomic differentiation is not necessarily possible between the genus Erythrobacter and the two phylogenetically related genera Porphyrobacter and Erythromicrobium (Fuerst et al., 1993; Rainey et al., 2003; Yurkov et al., 1994). Strains SW-110 ${ }^{\mathrm{T}}$, SW-116 and SW-140 show nearly identical phenotypic characteristics (Table 1). The three strains are also phylogenetically and genetically similar. In view of these combined data, strains SW-110 ${ }^{\mathrm{T}}$, SW-116 and SW-140 should be considered as members of the same species. There are some physiological differences between strains SW-110 $0^{\mathrm{T}}$, SW-116 and SW-140 and other Erythrobacter species, including the ability to utilize some substrates (Table 1). Therefore, on the basis of phenotypic, chemotaxonomic and phylogenetic data and genomic distinctiveness, strains SW-110 ${ }^{\mathrm{T}}$, SW-116 and SW-140 should be placed in the genus Erythrobacter as a novel species, for which the name Erythrobacter aquimaris sp. nov. is proposed.

\section{Description of Erythrobacter aquimaris sp. nov.}

Erythrobacter aquimaris (a.qui.ma'ris. L. n. aqua water; L. gen. n. maris of the sea; N.L. gen. n. aquimaris of the water of the sea).

Cells are rod-shaped $(0 \cdot 6-0 \cdot 9 \times 2 \cdot 0-4 \cdot 0 \mu \mathrm{m})$, non-sporeforming and non-motile. Colonies on MA $\left(5\right.$ days, $\left.30^{\circ} \mathrm{C}\right)$ are $1.0-2.0 \mathrm{~mm}$ in diameter, smooth, glistening, circular, convex and orange-pigmented. Growth occurs at 10 and $40{ }^{\circ} \mathrm{C}$, but not at 4 or above $42^{\circ} \mathrm{C}$. Optimal pH for growth is 6.5-7.5; growth is not observed at $\mathrm{pH} 5 \cdot 0$. Optimal growth occurs in the presence of $2-3 \%(\mathrm{w} / \mathrm{v}) \mathrm{NaCl}$; growth does not occur in the absence of $\mathrm{NaCl}$ or in the presence of more than $10 \% \mathrm{NaCl}$. Growth does not occur under anaerobic conditions on MA. Urease-negative. Aesculin, Tweens 20, 40, 60 and 80 and tyrosine are hydrolysed. Casein, hypoxanthine and xanthine are not hydrolysed. $\mathrm{H}_{2} \mathrm{~S}$ is not produced. Acid is not produced from adonitol, L-arabinose, D-cellobiose, D-fructose, D-galactose, D-glucose, myo-inositol, lactose, maltose, D-mannitol, D-mannose, D-melezitose, melibiose, D-raffinose, L-rhamnose, D-ribose, D-sorbitol, stachyose, sucrose, D-trehalose or D-xylose. Butyrate is utilized; formate, methanol, ethanol and benzoate are not. The predominant respiratory lipoquinone is Q-10. The predominant fatty acids are $\mathrm{C}_{18: 1} \omega 7 c$ and $\mathrm{C}_{17: 1} \omega 6 c$. The DNA $\mathrm{G}+\mathrm{C}$ content is $62 \cdot 2-62 \cdot 9 \mathrm{~mol} \%$ ( $62 \cdot 2 \%$ for the type strain) (determined by HPLC).

The type strain, SW $-110^{\mathrm{T}}\left(=\mathrm{KCCM} 41818^{\mathrm{T}}=\mathrm{JCM} 12189^{\mathrm{T}}\right)$, 
and reference strains SW-116 $(=\mathrm{KCCM} 41819=\mathrm{JCM}$ $12190)$ and SW-140 ( = KCCM $41820=$ JCM 12191) were isolated from sea water of a tidal flat of the Yellow Sea in Korea.

\section{Acknowledgements}

This work was supported by the 21C Frontier Programme of Microbial Genomics and Applications (grant MG02-0401-001-1-0-0) from the Ministry of Science and Technology (MOST) of the Republic of Korea.

\section{References}

Anzai, Y., Kim, H., Park, J.-Y., Wakabayashi, H. \& Oyaizu, H. (2000). Phylogenetic affiliation of the pseudomonads based on 16S rRNA sequence. Int J Syst Evol Microbiol 50, 1563-1589.

Bruns, A., Rohde, M. \& Berthe-Corti, L. (2001). Muricauda ruestringensis gen. nov., sp. nov., a facultatively anaerobic, appendaged bacterium from German North Sea intertidal sediment. Int J Syst Evol Microbiol 51, 1997-2006.

Cowan, S. T. \& Steel, K. J. (1965). Manual for the Identification of Medical Bacteria. London: Cambridge University Press.

Denner, E. B. M., Vybiral, D., Kobližek, M., Kämpfer, P., Busse, H.-J. \& Velimirov, B. (2002). Erythrobacter citreus sp. nov., a yellow-pigmented bacterium that lacks bacteriochlorophyll a, isolated from the western Mediterranean Sea. Int J Syst Evol Microbiol 52, 1655-1661.

Ezaki, T., Hashimoto, Y. \& Yabuuchi, E. (1989). Fluorometric deoxyribonucleic acid-deoxyribonucleic acid hybridization in microdilution wells as an alternative to membrane filter hybridization in which radioisotopes are used to determine genetic relatedness among bacterial strains. Int J Syst Bacteriol 39, 224-229.

Felsenstein, J. (1981). Evolutionary trees from DNA sequences: a maximum likelihood approach. J Mol Evol 17, 368-376.

Felsenstein, J. (1993). PHYLIP: Phylogenetic Inference Package, version 3.5. Distributed by the author. Department of Genetics, University of Washington, Seattle, USA.

Fuerst, J. A., Hawkins, J. A., Holmes, A., Sly, L. I., Moore, C. J. \& Stackebrandt, E. (1993). Porphyrobacter neustonensis gen. nov., sp. nov., an aerobic bacteriochlorophyll-synthesizing budding bacterium from fresh water. Int J Syst Bacteriol 43, 125-134.

Jukes, T. H. \& Cantor, C. R. (1969). Evolution of protein molecules. In Mammalian Protein Metabolism, vol. 3, pp. 21-132. Edited by H. N. Munro. New York: Academic Press.

Kluge, A. G. \& Farris, F. S. (1969). Quantitative phyletics and the evolution of anurans. Syst Zool 18, 1-32.

Komagata, K. \& Suzuki, K. (1987). Lipids and cell-wall analysis in bacterial systematics. Methods Microbiol 19, 161-203.
Lanyi, B. (1987). Classical and rapid identification methods for medically important bacteria. Methods Microbiol 19, 1-67.

Leifson, E. (1963). Determination of carbohydrate metabolism of marine bacteria. J Bacteriol 85, 1183-1184.

Levring, T. (1946). Some culture experiments with Ulva and artificial seawater. K Fysiogr Sallsk Lund Forh 16, 45-56.

Rainey, F. A., Silva, J., Nobre, M. F., Silva, M. T. \& da Costa, M. S. (2003). Porphyrobacter cryptus sp. nov., a novel slightly thermophilic, aerobic, bacteriochlorophyll a-containing species. Int J Syst Evol Microbiol 53, 35-41.

Saitou, N. \& Nei, M. (1987). The neighbor-joining method: a new method for reconstructing phylogenetic trees. Mol Biol Evol 4, 406-425.

Sasser, M. (1990). Identification of Bacteria by Gas Chromatography of Cellular Fatty Acids. Newark, DE: MIDI Inc.

Shiba, T. \& Simidu, U. (1982). Erythrobacter longus gen. nov., sp. nov., an aerobic bacterium which contains bacteriochlorophyll $a$. Int $J$ Syst Bacteriol 32, 211-217.

Tamaoka, J. \& Komagata, K. (1984). Determination of DNA base composition by reverse-phase high-performance liquid chromatography. FEMS Microbiol Lett 25, 125-128.

Thompson, J. D., Higgins, D. G. \& Gibson, T. J. (1994). CLUSTAL W: improving the sensitivity of progressive multiple sequence alignment through sequence weighting, position-specific gap penalties and weight matrix choice. Nucleic Acids Res 22, 4673-4680.

Vybiral, D., Denner, E. B. M., Haller, C. M., Busse, H.-J., Witte, A., Höfle, M. G. \& Velimirov, B. (1999). Polyphasic classification of $0 \cdot 2 \mu \mathrm{m}$ filterable bacteria from the Western Mediterranean Sea. Syst Appl Microbiol 22, 635-646.

Wayne, L. G., Brenner, D. J., Colwell, R. R. \& 9 other authors (1987). Report of the ad hoc committee on reconciliation of approaches to bacterial systematics. Int J Syst Bacteriol 37, 463-464.

Yoon, J.-H., Kim, H., Kim, S.-B., Kim, H.-J., Kim, W. Y., Lee, S. T., Goodfellow, M. \& Park, Y.-H. (1996). Identification of Saccharomonospora strains by the use of genomic DNA fragments and rRNA gene probes. Int J Syst Bacteriol 46, 502-505.

Yoon, J.-H., Lee, S. T. \& Park, Y.-H. (1998). Inter- and intraspecific phylogenetic analysis of the genus Nocardioides and related taxa based on 16S rDNA sequences. Int J Syst Bacteriol 48, 187-194.

Yoon, J.-H., Kim, H., Kim, I.-G., Kang, K. H. \& Park, Y.-H. (2003). Erythrobacter flavus sp. nov., a slight halophile from the East Sea in Korea. Int J Syst Evol Microbiol 53, 1169-1174.

Yurkov, V., Stackebrandt, E., Holmes, A. \& 7 other authors (1994). Phylogenetic positions of novel aerobic, bacteriochlorophyll $a$-containing bacteria and description of Roseococcus thiosulfatophilus gen. nov., sp. nov., Erythromicrobium ramosum gen. nov., sp. nov., and Erythrobacter litoralis sp. nov. Int J Syst Bacteriol 44, 427-434. 